\title{
CORRECTION
}

\section{Correction to: Myocardial ischemia due to radical resection of complex coronary fistulas with giant aneurysms: a case report}

\author{
Satoru Maeba ${ }^{1}$ (i) $\cdot$ Masatoshi Sunada ${ }^{1} \cdot$ Takuya Ito $^{1} \cdot$ Fumitaka Suzuki $^{1}$
}

Published online: 4 June 2021

(C) The Japanese Association for Thoracic Surgery 2021

\section{Correction to: General Thoracic and Cardiovascular Surgery https://doi.org/10.1007/s11748-021-01642-0}

In the original publication of the article, a supplementary video has been published incorrectly and it was removed.

The original article has been corrected.

Publisher's Note Springer Nature remains neutral with regard to jurisdictional claims in published maps and institutional affiliations.

The original article can be found online at https://doi.org/10.1007/ s11748-021-01642-0.

Satoru Maeba

cardiosatoru@hotmail.com

1 Department of Cardiovascular Surgery, Tokyo General Hospital, 3-15-2 Egota, Nakano-ku, Tokyo 165-0022, Japan 